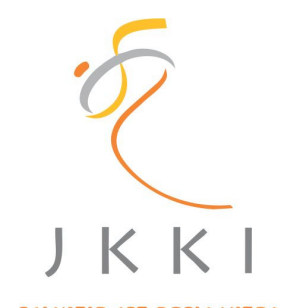

Jurnal Kedokteran dan Kesehatan Indonesia

Indonesian Journal of Medicine and Health

SCIENTIR EST BASIC VITAE

Journal homepage: https://journal.uii.ac.id/JKKI

\title{
Effects of progressive muscle relaxation technique on affective and somatic signs in nursing students taking objective structured clinical examination
}

Nurvita Risdiana*1, Jefry Leo Sandy ${ }^{1}$, Johan ${ }^{1}$

${ }^{1}$ School of Nursing, Faculty of Medicine and Health Sciences, Universitas Muhammadiyah Yogyakarta, Bantul, Indonesia

Original Article

\begin{tabular}{l}
\hline \\
\hline ART ICLE INF O \\
\hline Keywords: \\
Affective sign, \\
Progressive Muscle Relaxation, \\
Somatic sign \\
\hline *Corresponding author: \\
nurvita.risdiana@umy.ac.id \\
\hline DOI: 10.20885/JKKI.Vol12.Iss1art10 \\
History: \\
Received: August 16, 2020 \\
Accepted: April 12, 2021 \\
Online: April 30, 2021 \\
\hline
\end{tabular}

Copyright @2021 Authors. This is an open access article distributed under the terms of the Creative Commons Attribution-NonCommercial $\quad 4.0$ International Licence (http:// creativecommons.org/licences/ by-nc/4.0/).

\section{ABSTRACT}

Background: Objective Structured Clinical Examination (OSCE) is an instrument for an evaluation test to asses observable skills. However, this situation of the test can lead to anxiety for students expressed in affective and somatic signs. Progressive muscle relaxation technique is one of nonpharmacology therapies and can be used to decrease the affective and somatic signs in the students.

Objective: This study aims to determine effects of the progressive muscle relaxation technique on affective and somatic signs in nursing students when taking the OSCE.

Methods: This study was a quasi-experimental with a pre-test and postgroup design. Fifty eight participants were selected by inclusion criteria and divided into two groups (a treatment group and a control group). The progressive muscle relaxation before the OSCE was conducted for 30 minutes. Zung's self-rating anxiety (ZSAS) was applied to measure the affective signs. A sphygmomanometer, manual heart rate palpation, and thorax inspection were used to measure the somatic signs. The data were analysed by using a Wilcoxon test.

Results: The Wilcoxon test showed that the effects of progressive muscle relaxation technique on the affective signs indicated p-value of 0.0001 $(p<0.005)$. Then it also affected the somatic signs as occurred in systolic blood pressure with $\mathrm{p}$-value of 0.00 , diastolic blood pressure with $\mathrm{p}$-value of 0.004 , heart rate with $p$-value of 0.00 , and respiration rate with $p$-value of 0.00 . The affective and somatic signs in the treatment group decreased after the treatment was given. However, they were not found in the control group.

Conclusion: There are effects of progressive muscle relaxation technique on affective and somatic signs in nursing students when taking the OSCE. The affective and somatic signs in the treatment group were lower than in the control group.

Latar Belakang: Objective Structured Clinical Examination (OSCE) adalah suatu alat ukur yang bersifat objektif dan terstruktur untuk mengukur keterampilan klinik pada mahasiswa medis. Pelaksanaan OSCE seringkali menimbulkan kecemasan pada mahasiswa yang ditunjukkan dengan tanda afektif dan somatik. Teknik relaksasi otot progresif merupakan salah satu terapi nonfarmakologi yang dapat digunakan untuk menurunkan tanda afektif dan somatik.

Tujuan: Tujuan penelitian ini adalah untuk mengetahui pengaruh teknik relaksasi otot progresif terhadap tanda afektif dan somatik pada mahasiswa keperawatan yang menjalani OSCE. 
Metode: Penelitian quasi-experimental dengan desain pretest dan posttest. Lima puluh delapan responden yang terlibat dipilih sesuai dengan kriteria inklusi dan terbagi menjadi dua kelompok (intervensi dan kontrol). Instrumen yang digunakan adalah Zung self-rating anxiety (ZSAS) untuk mengukur tanda afektif. Sphygmomanometer, palpasi nadi manual dan inspeksi thorak digunakan untuk mengukur tanda somatik. Analisa data yang digunakan adalah Wilcoxon.

Hasil: Uji Wilcoxon menunjukkan adanya pengaruh teknik relaksasi otot progresif pada tanda afektif dengan $p=0.0001(p<0.05)$ dan juga tanda somatik tekanan darah sistolik dengan $p=0.004$, nadi dengan $p=0.00$ dan respirasi dengan $p=0.00$. Tanda afektif dan somatik pada kelompok intervensi menurun, namun tidak pada kelompok kontrol.

Kesimpulan: Terdapat pengaruh teknik relaksasi otot progresif pada tanda afektif dan somatik pada mahasiswa keperawatan. Tanda afektif dan somatik pada kelompok intervensi lebih rendah dibandingkan dengan kelompok kontrol.

\section{INTRODUCTION}

Objective Structured Clinical Examination (OSCE) is a an instrument to asses components of clinical skills such as physical examination, communication skills, interpretation of laboratory results, management skills, and other skills that are tested by using direct observation. ${ }^{1}$ This preclinical learning method will have its stressors. ${ }^{2}$ One of the stressors in the preclinical learning method is the OSCE. The OSCE is a standard method of clinical testing for medical students. ${ }^{1}$ The purpose of OSCE is to examine psychomotor, cognitive, and professional behavioural aspects by using a checklist or an assessment standard that have been determined so that it requires students to work faster and more precisely. ${ }^{3}$ This assessment will affect student performance during the OSCE. Several studies have shown that student performance during the OSCE is influenced by several individual factors such as anxiety, selfconfidence, and preparation. ${ }^{4}$ Besides, some studies from several countries found that anxiety levels of medical students reaches $80 \%$ during the OSCE. ${ }^{4}$

The situation during the test requires the students to perform high standards and competitive skills that will increase their anxiety. ${ }^{5}$ Consequently, the increasing anxiety will affect the OSCE results that may cause their grades lower. Anxiety is a condition when an individual experiencing a sense of worry. Hence, activation of sympathetic nervous system increases as a result of an existing threat. ${ }^{6}$

Individuals who experience anxiety show affective and somatic symptoms. ${ }^{7,8}$ The affective signs include signs of anxiety experienced by an individual, and the somatic signs include rapid breathing, increasing blood pressure, and pulse. Students need to overcome the increase of affective and somatic symptoms. Therefore, the students will focus and concentrate on activities conducted during the OSCE.

For the OSCE, the students need to have careful preparations so that they are able to concentrate. One of the preparations is to overcome anxiety. The anxiety can be solved in some ways by both pharmacological and nonpharmacological ways. In an anxiety condition, non-pharmacological therapies are considered as a good recommendation. Then progressive muscle relaxation technique is one of the nonpharmacological therapies that can be applied because it is categorized as mild anxiety. ${ }^{9}$ This technique is recommended for mild anxiety because it is easy and has relaxation effects.

Relaxation can affect hypothalamus and parasympathetic nerves to reduce blood pressure, metabolism, and respiration. As a result, it reduces oxygen consumption and decrease muscle tension. ${ }^{10}$ Relaxation can stimulate the emergence of chemicals resembling beta-blockers in the peripheral nerves so that it can close sympathetic nerve nodes that are useful for reducing tension and blood pressure. ${ }^{11}$ According to Edmund Jacobs, the progressive muscle relaxation involved several types of muscles in the body such as wrist muscles, forearm muscles, elbow muscles, upper arm muscles, shoulder muscle groups, head and neck muscles, facial muscles, back muscles, chest muscles, stomach muscles, and leg and thighs muscles. ${ }^{12}$ In some cases of mild anxiety, the 
progressive muscle relaxation technique can control breathing and reduce anxiety so that some emotion can be controlled. ${ }^{12}$

The progressive muscle relaxation technique is still rarely used in reducing mild anxiety, especially in students approaching the OSCE. This simple and easy technique can be an option to overcome anxiety among the students. Therefore, this study aims to determine effects of the progressive muscle relaxation technique on affective and somatic signs in nursing students who are preparing for the OSCE.

\section{METHODS}

\section{Research design}

This study was a quasi-experimental study with a pre-test and post-test group design that applied a cross-sectional approach. This study was agreed by the Commission of Ethics, Faculty of Medicine and Health Sciences, Universitas Muhammadiyah Yogyakarta, No. 058/ EPFKIK-UMY/ II/ 2017. The respondents also got explanation of this research procedures and signed an informed consent.

\section{Subjects and population}

The population of this study was the fourthyear nursing students of Faculty of Medicine and Health Sciences, Universitas Muhammadiyah Yogyakarta. This study was conducted in 2017 with a population number of 117 students. According to Arikunto, the calculated samples were $25 \%$ from the total population, and a number of total respondents that was excluded was 58 respondents divided into two groups. ${ }^{13}$ The exclusion criteria in this study were the students who consume antidepressant. The inclusion criteria grup were the nursing students who would take the OSCE on a day when the data were collected and who were willing to be respondents in this study. The groups were the treatment group and the control group. The pre-test and post-test were conducted to determine the affective and somatic signs on the students who will participate the OSCE before and after the progressive muscle relaxation. Affective and somatic sign measurement
The affective sign measurement was conducted to determine the signs of anxiety by applying Zung's self-rating anxiety (ZSAS) questionnaire. The questionnaire consisted of 20 statements divided into 5 statements on attitudes and 15 statements on affective signs. The statements in this questionnaire focused on the most common disorders occurred in anxiety. To assess the levels of anxiety, the data were classified into four categories based on a number of scores obtained by the respondents. The score ranging from 20 to 44 meant that the respondents did not experience anxiety. The score ranging from 45 to 59 meant that the respondents experienced mild anxiety. The score ranging from 60 to 74 meant that the respondents experienced moderate anxiety. Meanwhile, the score ranging from 75 to 80 meant that the respondents experienced severe anxiety.

The measurement of somatic signs included blood pressure, pulse, and respiration measurement by using a sphygmomanometer, manual heart rate palpation, and thorax inspection. ${ }^{14}$

\section{Preparatory stage}

The stages of this study (Figure 1) were performed in two stages: a preparatory stage conducted one week before collecting data and a data collection stage itself. The preparatory stage included explanation of research procedures and selection of respondents. The selection of respondents was based on the inclusion criteria. The data collection stage consisted of three steps, namely pre-test, treatment, and post-test for the treatment group, and the control group was only given pre-test and post-test. The pretest and post-test were to measure the affective and somatic signs which were measured by the researchers it self at the same time between the treatment and control group.

\section{Experimental stage: progressive muscle relaxation therapy}

In the experimental stage, the students of the experimental group had progressive 


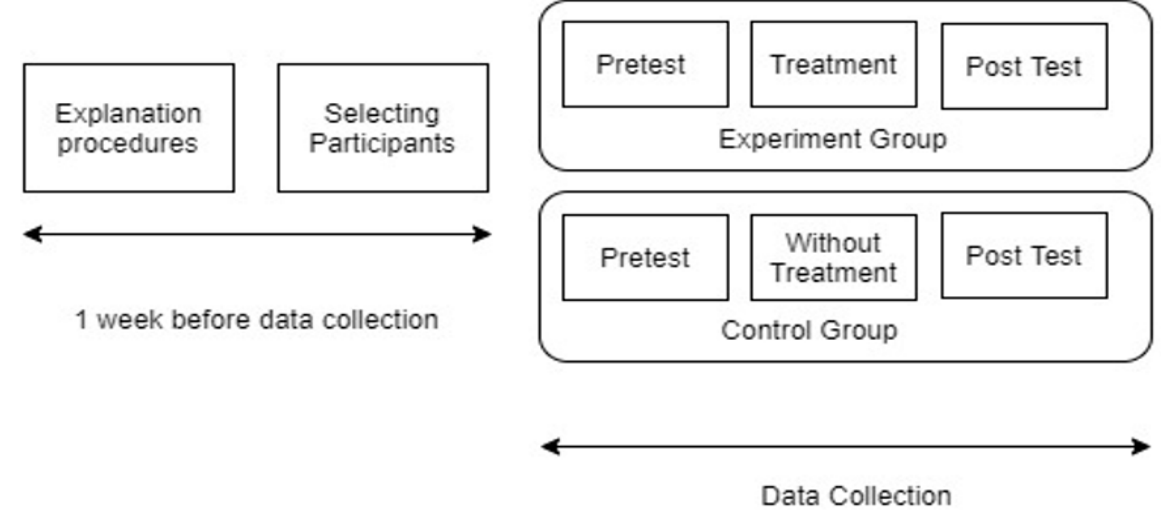

Figure 1. Research Stages

muscle relaxation therapy guided by the two researchers for approximately 30 minutes before the OSCE. In this demonstration, each student was provided a module on how to do the therapy. The researchers also explained the procedure by using a loudspeaker. The procedures of progressive muscle relaxation technique are as follows: 1 . The students start by taking a deep breath three times. They breathe in the air through their nose and breathe out the air slowly through their mouth; 2 . The students clench both of their hands and tighten their biceps and forearms. They are guided to tense their muscles. They are asked to think about the sense and the muscle tension completely. Then, they are asked to relax; 3 . They wrinkle up their forehead. After that, they press the head as far as possible to the back. Next, they turn their head around clockwise and vice versa. Then, they are asked to relax again; 4 . They bend their back to the back while taking a deep breath. After that they hold it and relax; 5. They pull back their feet and thumbs toward their face. Then, they hold these for a moment and relax. Next, they fold their thumbs simultaneously and tighten their calves, thighs, and buttocks. Then, they relax again. After finished, the affective and somatic signs were immediately measured.

\section{Statistical analysis}

A data analysis applied in this study was univariate and bivariate analysis. Univariate analysis was in a form of frequency distribution, and a Wilcoxon test was used to determine the effects of progressive muscle relaxation technique on affective and somatic signs.

\section{RESULTS}

The results (Table 1) showed the students' levels of anxiety before given the intervention. It was found that 18 respondents (62\%) experienced mild anxiety level. Meanwhile, there were 11 respondents (38\%) having moderate anxiety. On the other hand, in the control group, there were 21 respondents $(72.41 \%)$ experiencing mild anxiety and 8 respondents (27.59\%) having moderate anxiety. Based on the data above, it could be concluded that students who were going to take an OSCE would experience mild and moderate anxiety levels. Most of the students would experience anxiety in different levels before the OSCE according to a coping mechanism they had. Various anxiety levels of the samples in this study could be found although it was conducted by a same stressor.

Table 2 demonstrated that the intervention group had a mean \pm standard deviation in systolic blood pressure, diastolic blood pressure, pulse, and respiration as described in the following: $119.48 \pm 6.98 \mathrm{mmHg}, 82.17 \pm 6.79 \mathrm{mmHg}, 79.48 \pm$ 7.27 beats/minute, $23.34 \pm 3.75$ breaths/minute. Meanwhile, in the control group, the systolic blood pressure, the diastolic blood pressure, pulse, and respiration were presented as follows $115.86 \pm 7.32 \mathrm{mmHg}, 79.65 \pm 6.80 \mathrm{mmHg}, 75.17$ \pm 10.27 beats / minute and $22.62 \pm 2.39$ breaths/ minute (Table 2). 


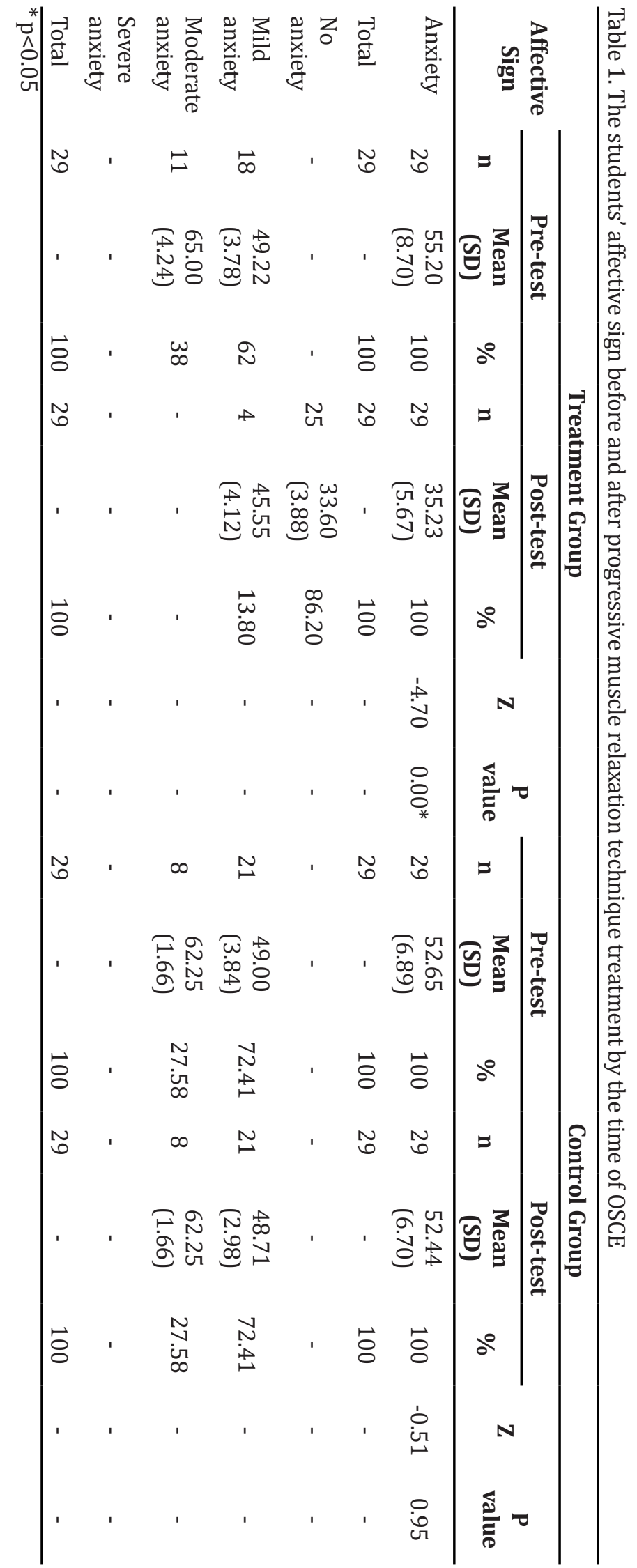




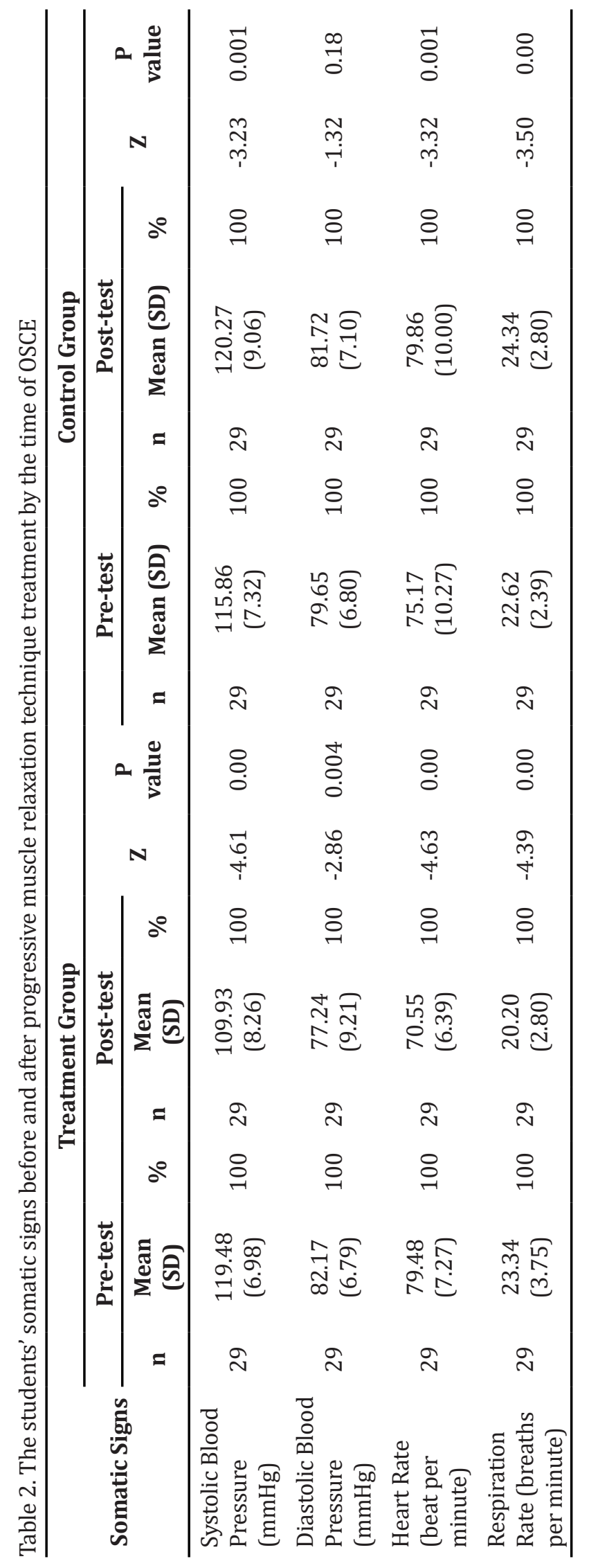




\section{DISCUSSION}

Anxiety is a negative emotional feeling characterized by feeling worried and followed by specific somatic, cognitive, and behavioural changes. ${ }^{8}$ When feeling anxious, the brain's role is very influential in recognizing and regulating stimuli causing somatic, cognitive, and behavioural responses as well. ${ }^{8}$ In general, the amygdala has a vital role in causing anxiety. ${ }^{15}$ In this study, the tense perception on OSCE raises anxiety in the students. Some studies suggest that stress can induce changes in GABA and GABA receptors in the amygdala. ${ }^{16}$ Thus, an OSCE as a stressor can produce hyper-reactive amygdala and raise anxiety in the students as indicated by mild and moderate anxiety in both the intervention and control groups. Based on the data above, it can be concluded that students who are going to take the OSCE can experience mild and moderate anxiety levels.

Most of the students will experience anxiety in different levels before the OSCE according to a coping mechanism they have. The coping mechanism is a human strategy to manage the stress. Various anxiety levels of the samples in this study can be found although it is conducted by a same stressor Additionally, a psychodynamic theory explains that anxiety is a result of psychological conflict that occurs when the ego functions as a defence mechanism against the stressors. This self-defence mechanism will be considered as a sign and a symptom of anxiety. Some appearing signs depend on how an individual is able to manage a received stimulus. Beside anxiety, the self-defence mechanism known as a fight or a flight mechanism also contributes in the anxious condition to maintain homeostasis. ${ }^{17}$ The stressors received by the amygdala will activate the fight or the flight mechanism and can cause changes in the body metabolism.

An activation of a stress will stimulate the autonomic nervous system, sympathetic nerves; as a result, there are changes on particular organ targets. For example, there will be an increase in the pulse, in the blood pressure and in the respiration of the cardiorespiratory system.
Beside the levels of anxiety experienced by the students, based on the theory of fight or flight mechanism, there are also changes in the cardiorespiratory system including changes in blood pressure, pulse and respiration.

Relaxation skills are very useful for developing abilities to stay calm or to avoid stress when facing difficulties. Being always relaxed will make an individual have control in life. This progressive muscle relaxation is performed by involving the brain and muscles to work together.$^{18}$ Therefore, the muscles and the body can feel relaxed so that activities of the sympathetic nerves can be less tense. When an individual is getting tenser in a particular situation, the muscles of the body will increase the tension that can cause a feeling of anxiety.

The relaxation technique has some benefits. Firstly, the relaxation makes and individual more able to avoid excessive reactions due to stress or anxiety. Secondly, the relaxation is very useful for developing abilities to stay calm or to avoid stress when facing difficulties. Progressive muscle relaxation technique is a therapy for anxiety disorders. ${ }^{9}$ When the activities of relaxation activate the parasympathetic nerves, it can cause lower blood pressure, pulse, and respiration. ${ }^{7}$

In this study, after progressive muscle relaxation technique is performed, there is a decrease in the affective signs in the treatment group. On the contrary, there is no difference in the control group. Similarly, in the somatic signs found in the treatment group, there are differences in the blood pressure, pulse, and respiration before and after the progressive muscle relaxation technique is performed. The somatic signs are lower after the treatment, except in the control group. Somatic signs in the control group tend to increase.

Based on this result, it can be concluded that progressive muscle relaxation technique can reduce the affective and somatic signs. The affective signs decrease as shown by the decreased anxiety compared to the control group. Likewise, the somatic signs also decrease as shown by the decreased of the mean values of blood pressure, pulse, and respiration compared 
to the control group. These results are consistent with a study conducted by Astuti, et al. stating that progressive muscle relaxation technique can reduce anxiety. ${ }^{19}$ In addition, a study by Ain et al. also demonstrates similar results reporting that progressive muscle relaxation technique can reduce systolic blood pressure but not the diastolic blood pressure. ${ }^{20}$

The mechanism of blood pressure regulation in the body is divided into two types of pressure namely working fast regulation and long term regulation. ${ }^{21}$ The mechanisms working fast include nerve mechanisms (central nerves and autonomic nerves) and hormonal mechanisms. The rationale of the method of the progressive muscle relaxation is to utilize the regulation of the central nerves and autonomic nerves. The sympathetic nerves work to increase stimulation or to stimulate the body's organs. They trigger an increase of heart rate, a cause of blood vessel constriction, and a decrease of temperature. ${ }^{10}$

The goal of progressive muscle relaxation is to reduce the oxygen consumption of the body, the body metabolism rate, respiratory rate, muscle tension, premature ventricular contraction, systolic blood pressure, and the brain's alpha waves. The relaxation also functions to decrease the work of the sympathetic nerve system by increasing the activities of the parasympathetic nerves. When individuals experience tension and anxiety in the sympathetic nerves system, the heart rate, the blood pressure, the blood flow to the muscles, and dilated pupils often increase. ${ }^{22}$ In the control group, there is no progressive muscle relaxation technique is performed; the results show that there is no decrease in the affective signs with a value of 0.95 . Similarly, there is no decrease in somatic signs found in the diastolic blood pressure with a $p$ value of 0.18 . In addition, there is an increase in somatic signs found in the blood pressure with a p value of 0.001 . There are some increases in pulse with a value of 0.001 , in respiration with the $p$ value of 0.00 .

Mild activity during the relaxation will stimulate the parasympathetic nerves that can stimulate endocrine glands to release both epinephrine and norepinephrine. During the activity, the parasympathetic nerves of epinephrine will bind to cardiac enzymes and strengthen a local vasodilator mechanism in the lung tissues. Consequently, it will produce bronchodilation causing the air to flow in and out more smoothly. As a result, rates of peak expiratory flow will be able to increase, and there will be also a decrease in respiratory frequency. ${ }^{23}$

The relaxation skills are very useful for developing the abilities to stay calm or to avoid stress when facing difficulties. Being always relaxed will make an individual to have control in life. When an individual becomes tenser in particular situations, the body's muscles will increase tension. As a result, an individual feels anxious. This situation tends to raise a prolonged cycle and tends to get worse if it is put aside. The progressive muscle relaxation therapy aims to cut the circle of this cycle so that the tension and anxiety do not increase. This condition will make individuals become more relaxed, more comfortable, and more able to overcome some problems faced by applying some methods that are more appropriate.

\section{CONCLUSION}

There are effects of the progressive muscle relaxation technique on affective and somatic signs in nursing students taking the OSCE. The affective and somatic signs are lower with the treatment of progressive muscle relaxation technique. The progressive muscle relaxation can reduce the mild and moderate levels of anxiety.

\section{CONFLICT OF INTEREST}

There is no conflict of interest in this study.

\section{ACKNOWLEDGEMENT}

The authors thank for all undergraduate students who participated in this study and for Skills Laboratory School of Nursing, Faculty of Medicine and Health Sciences, Universitas Muhammadiyah Yogyakarta.

\section{REFERENCES}

1. Zayyan M. Objective structured clinical 
examination: The assessment of choice. Omanan Medical Journal. 2011;26(4):21922.

2. Wahjudi JW, Findyartini A, Kaligis F. The relationship between empathy and stress: A cross-sectional study among undergraduate medical students. Korean Journal of Medical Education. 2019;31(3):215-26.

3. Hetaimish B, Frcs C, Elbadawi H. OSCE assessment for medical student clinical skills and performance, are we doing it the right way? International Journal of Science and Research. 2015;4(11):963- 7.

4. Kim KJ. Factors associated with medical student test anxiety in objective structured clinical examinations: A preliminary study. International Journal of Medical Education. 2016;7:424-7.

5. Zartman RR, McWhorter AG, Seale NS, Boone WJ. Using OSCE-based evaluation: Curricular impact over time. Journal of Dental Education. 2002;66(12):1323-30.

6. Roth WT, Doberanz S, Dietel A, Conrad A, Mueller A, Wollburg, et al. NIH Public Access. Journal of Psychiatric Research. 2008;42(3):205-12.

7. Anderson SM, Brunzell DH. Low dose nicotine and antagonism of $\beta 2$ subunit containing nicotinic acetylcholine receptors have similar effects on affective behavior in Mice. PLoS One. 2012;7(11):1-11.

8. Nuss P. Anxiety disorders and GABA neurotransmission: A disturbance of modulation. Neuropsychiatric Disease and Treatment . 2015;11:165-75.

9. Ain H, Hidayah N, Marsaid. Effect of progressive muscle relaxation on anxiety in geriatric population. International Journal of Research and Scientific Innovation. 2018;V(XI):25-30.

10. Starr C, McMillan B. Human Biology. Eleventh E. Deselle K, editor. Boston: Cengage Learning,2016.

11. Tyani ES, Utomo W, Hasneli Y. Efektifitas relaksasi otot progresif terhadap tekanan darah pada penderita hipertensi esensial. Jurnal Online Mahasiswa. 2015;2(37):1068-75.

12. Ramasamy S, Panneerselvam S, Govind- haraj P, Kumar A, Nayak R. Progressive muscle relaxation technique on anxiety and depression among persons affected by leprosy. Journal of Exercise Rehabilitation. 2018;14(3):375- 81.

13. Arikunto S. Prosedur penelitian suatu pendekatan praktik. Jakarta: Rineka Cipta,2010.

14. Zung WWK. A rating instrument for anxiety disorders. Journal of The American Academy of Psychosomatic Medicine. 1971;XII(6):371-9.

15. Zhang X, Ge TT, Yin G, Cui R, Zhao G, Yang W. Stress-induced functional alterations in amygdala: Implications for neuropsychiatric diseases. Frontiers in Neuroscience. 2018;12(MAY):1-9.

16. Prager EM, Bergstrom HC, Wynn GH, Braga MFM. The basolateral amygdala GABAergic system in health and disease HHS Public Access. Journal of Neuroscience Research. 2016;94(6):548-67.

17. Goldstein DS. Adrenal responses to stress. Cellular and Molecular Neurobiology. 2010;30(8):1433-40.

18. Safi SZ. A fresh look at the potential mechanisms of progressive muscle relaxation therapy on depression in female patients with multiple sclerosis. Iranian Journal of Psychiatry and Behavioral Science. 2015;9(1):1-7.

19. Astuti A, Anggorowati A, Johan A. Effect of progressive muscular relaxation on anxiety levels in patients with chronic kidney disease undergoing hemodialysis in the General Hospital of Tugurejo Semarang, Indonesia. Belitung Nursing Journal. 2017;3(4):383-9.

20. Kozako IN 'Ain MF, Safin SZ, Rahim ARA. The relationship of big five personality traits on counterproductive work behaviour among Hotel Employees: An exploratory Study. Procedia Economics and Finance 2013;7(Icebr):181-7.

21. Sherwood L. Human Physiology: From celss to systems. Eighth Edi. Alexander S, Glubka A, Oliveira L, editors. Belmont: Yolanda Cossio,2013.

22. Lindquist R, Snyder M, Tracy MF. Com- 
plementary and alternative therapies in nursing, 7th edition. Seventh Ed. Vol. 34, Critical Care Nurse. New York: Springer Publishing Company,2014. p:76-76.

23. Hinkle JL, Cheever KH. Textbook of Medical Surgical Nursing. 13th Editi. Reilly D, editor. Wolters Kluwer Health | Lippincott Williams \& Wilkins; 2010. 